\title{
Hubungan sedentary lifestyle dengan fungsi kognitif lansia di UPT Pelayanan Sosial Tresna Werdha Jember
}

\author{
Ega Putri Nurwita, ${ }^{1}$ Tantut Susanto, ${ }^{1,{ }^{*}}$ Hanny Rasni ${ }^{1}$ \\ ${ }^{1}$ Departemen Keperawatan Komunitas, Keluarga, dan Gerontik, Fakultas Keperawatan, Universitas \\ Jember, Jember, Indonesia
}

\author{
Submitted: 16 Februari 2019 Revised: 7 Maret 2019 Accepted: 10 Maret 2019
}

\begin{abstract}
ABSTRAK Gangguan fungsi kognitif pada lansia merupakan salah satu masalah yang ditemukan di Indonesia. Fungsi kognitif berkaitan dengan gaya hidup seseorang misalnya aktivitas fisik. Aktivitas fisik mampu meningkatkan pertumbuhan saraf otak sehingga mempengaruhi fungsi kognitif lansia. Namun mayoritas lansia lebih memilih menerapkan sedentary lifestyle. Sedentary merupakan gaya hidup dengan menerapkan perilaku duduk, bersandar, dan berbaring yang dilakukan mulai dari bangun tidur hingga sebelum tidur malam secara terus-menerus. Tujuan penelitian ini yaitu menganalisis hubungan antara sedentary lifestyle dengan fungsi kognitif lansia (lansia) di Unit Pelaksana Teknis Pelayanan Sosial Tresna Werdha (UPT PSTW) Jember. Penelitian ini menggunakan desain cross-sectional pada 84 lansia yang tinggal di UPT PSTW Jember dengan convenience sampling. Sosiodemografi responden diukur menggunakan kuesioner, sedentary lifestyle diukur menggunakan Global Physical Activity Questionnaire (GPAQ), dan fungsi kognitif diukur menggunakan Mini Mental State Exam (MMSE). Penelitian ini menggunakan uji Spearman rank untuk menjawab tujuan penelitian. Lama waktu sedentary lifestyle pada 84 lansia di UPT PSTW adalah 405 menit/hari. Nilai tersebut lebih pendek dari pada nilai standar $(z=1,377 ; p=0,045)$. Lansia di UPT PSTW Jember memiliki nilai fungsi kognitif 27 . Nilai tersebut lebih tinggi daripada nilai standar $(Z=1,401$; $p=0,040$ ) sehingga lansia memiliki fungsi kognitif utuh. Sedentary lifestyle berhubungan dengan fungsi kognitif, semakin pendek waktu sedentary lifestyle maka fungsi kognitif semakin meningkat $(r=-0,470 ; p$ $<0,001)$. Oleh karena itu, diperlukan intervensi berupa pembuatan jadwal aktivitas fisik rutin dan latihan aerobik untuk mempertahankan fungsi kognitif lansia.
\end{abstract}

KATA KUNCl fungsi kognitif; lansia; sedentary lifestyle

ABSTRACT Cognitive function disorders in elderly is one of the problems found in Indonesia. Cognitive function is related to a person's lifestyle such as physical activity. Physical activity can increase brain nerve growth and affect cognitive function in elderly. However, the majority of the elderly choose sedentary lifestyle. Sedentary is a lifestyle by applying behavior when sitting, leaning back, and lying down which is done starting from waking up to the night before going to sleep continuously. The purpose of this study was to analyze the relationship between sedentary lifestyle and cognitive function among the elderly at UPT PSTW Jember. A cross-sectional design was conducted among 84 elderly at UPT PSTW Jember by using convenience sampling. A questionnaire was used to identify the sociodemography of participants while the data of sedentary lifestyle was obtained by using Global Physical Activity Questionnaire (GPAQ), and the data of cognitive function was taken using Mini Mental State Exam (MMSE). Spearman rank test was performed to answer the purpose of this study. Among 84 participants, it is shown that elderly are sedentary for 405 minutes/day, which are less than standard score $(Z=1.377 ; p=0.045)$. The cognitive function score of elderly is 27 which are greater than the standard score $(Z=1.401 ; p=0.040)$, so that the

\footnotetext{
*Corresponding author: Tantut Susanto

Departemen Keperawatan Komunitas, Keluarga, dan Gerontik, Fakultas Keperawatan, Universitas Jember, Jl. Kalimantan No. 37 Jember, Jawa Timur 68121, Indonesia

E-mail: tantut_s.psik@unej.ac.id
} 
elderly has normal cognitive function. The sedentary lifestyle is related to cognitive function, the shorter duration of sedentary lifestyle, the cognitive function increases $(r=-0.470 ; p<0.001)$. Therefore, it is needed an intervention such as make schedule routine for physical activity and aerobic exercise to maintain cognitive function in elderly.

KEYWORDS cognitive function; elderly; sedentary lifestyle

\section{Pendahuluan}

Gangguan fungsi kognitif pada lanjut usia (lansia) merupakan salah satu masalah yang ditemukan di Indonesia, dimana pada tahun 2015 lebih dari 556.000 lansia mengalami gangguan fungsi kognitif. ${ }^{1}$ Gangguan fungsi kognitif berkaitan dengan kondisi psikososial, tingkat pendidikan, dan gaya hidup, seperti aktivitas fisik dan sedentary lifestyle. ${ }^{2-5}$ Sedentary lifestyle merupakan perilaku duduk, bersandar, dan berbaring yang dilakukan mulai dari bangun tidur hingga sebelum tidur malam yang dilakukan terus-menerus. ${ }^{6}$ Umumnya, lansia memiliki banyak waktu luang dan mayoritas digunakan untuk sedentary sehingga waktu untuk beraktivitas fisik berkurang. Sedentary lifestyle dapat menghambat produksi neurotropin sehingga transmisi sinaps pada otak terganggu. ${ }^{7}$ Untuk itu, dibutuhkan perhatian khusus terhadap sedentary lifestyle pada lansia dan kaitannya dengan penurunan fungsi kognitif lansia.

Penurunan fungsi kognitif pada lansia di dunia tiap tahun meningkat sebanyak 77 juta kasus baru. ${ }^{8}$ Persentase penurunan fungsi kognitif lansia di Unit Pelaksana Teknis Pelayanan Sosial Tresna Werdha (UPT PSTW) Jember sebesar $67 \% .^{9}$ Penurunan fungsi kognitif terjadi pada aspek persepsi, respon, pengungkapan informasi, dan pemahaman bahasa. ${ }^{7}$ Gangguan fungsi kognitif dalam jangka waktu lama dapat menyebabkan timbulnya permasalahan baru, yaitu kesulitan pemenuhan aktivitas seharihari pada lansia akibat penurunan kemampuan mengingat dan memproses informasi. ${ }^{10}$ Lansia yang memiliki banyak waktu luang kemungkinan mengalami penurunan fungsi kognitif yang salah satu penyebabnya adalah sedentary lifestyle.

Lansia di Eropa menghabiskan $65-80 \%$ waktu mereka untuk sedentary lifestyle. ${ }^{11}$ Saat seseorang terbiasa dengan sedentary lifestyle, otak tidak distimulasi untuk memproduksi protein yang disebut brain derived neutrophic factor (BDNF). Protein tersebut berfungsi untuk menjaga sel saraf otak tetap sehat, dan hanya diproduksi apabila seseorang melakukan aktivitas fisik. ${ }^{7,12}$ Penelitian menganai penerapan intervensi aktivitas fisik pada responden dengan sedentary lifestyle menunjukkan bahwa aktivitas fisik mampu memperbaiki performa sistem kardiovaskular. Performa sistem kardiovaskular memengaruhi aliran darah di otak sehingga berkaitan dengan fungsi kognitif seseorang. ${ }^{13}$ Pada penelitian ini dilakukan pengkajian hubungan antara sedentary lifestyle dengan fungsi kognitif lansia di UPT PSTW Jember.

\section{Metode}

\subsection{Desain, sampel, dan pengambilan data}

Penelitian ini menggunakan desain potong lintang. Pada penelitian ini, dilakukan pemilihan 84 subjek dari 130 lansia di UPT PSTW Jember menggunakan metode convenience sampling. Sampel yang dipilih adalah lansia yang memenuhi kriteria inklusi dan eksklusi penelitian. Kriteria inklusi pada penelitian ini yaitu lansia yang bersedia menjadi responden. Kriteria eksklusi pada penelitian ini yaitu lansia dengan imobilitas total, tuna rungu dan wicara, tidak sedang berada di tempat penelitian, dan mempunyai nilai Mini Mental State Exam (MMSE) $\leq$ 18. Awalnya peneliti melakukan penapisan dengan cara memilah data lansia yang didapatkan dari petugas UPT PSTW Jember. Sebanyak 20 orang lansia yang mengalami imobilitas total tidak dijadikan sebagai sampel. Berdasarkan informasi petugas di UPT PSTW Jember, 5 orang lansia izin beberapa hari meninggalkan tempat untuk 


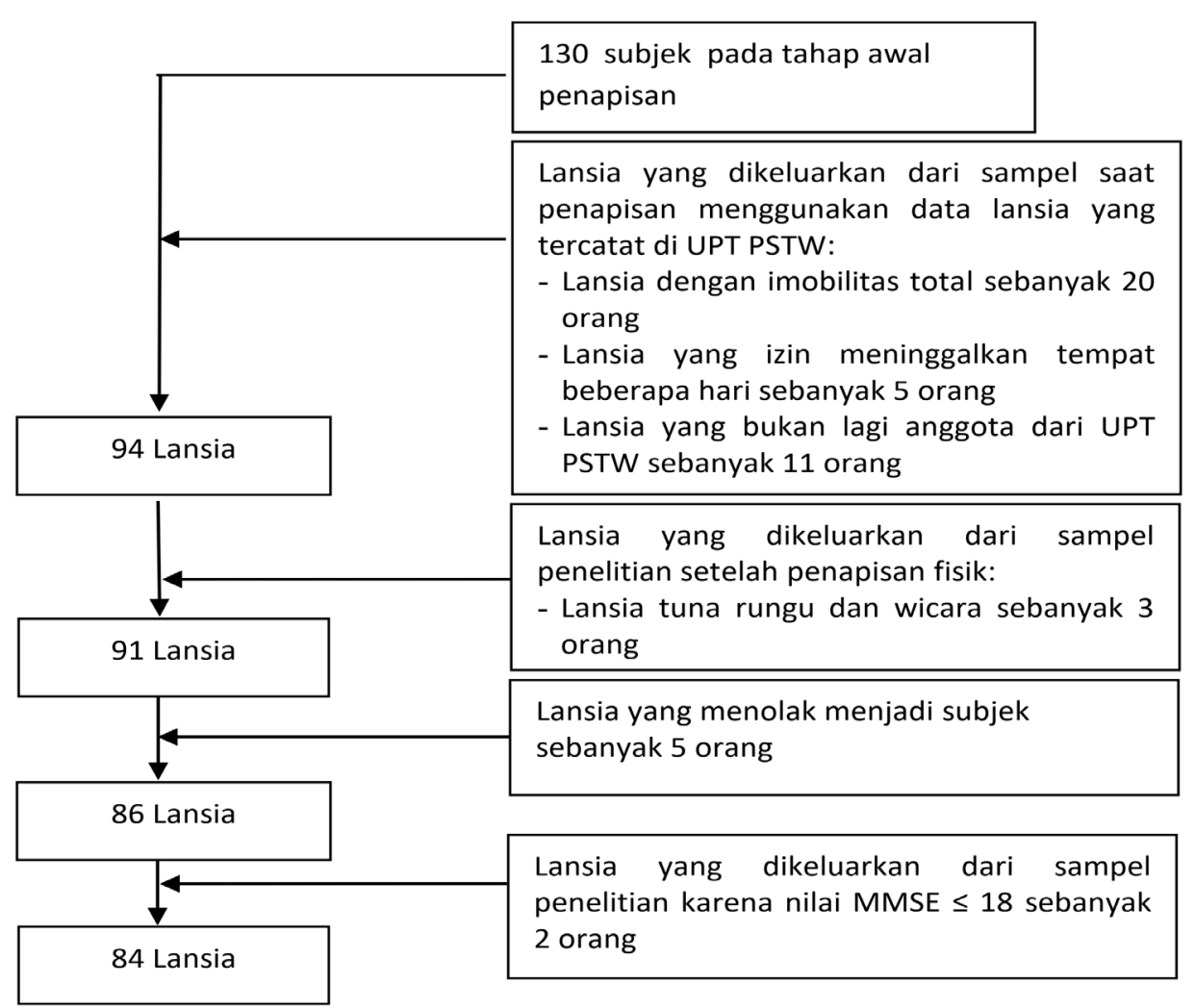

Gambar 1. Alur pengambilan sampel penelitian instrumen

mengunjungi keluarganya dan sebanyak 11 orang lansia bukan lagi anggota UPT PSTW dan sudah tidak tinggal di UPT PSTW Jember. Penapisan fisik yang dilakukan peneliti saat bertemu langsung dengan lansia mendapati bahwa 3 lansia tuna rungu dan wicara. Saat proses penelitian, 5 orang lansia menolak menjadi responden (Gambar 1 ).

Sebelum pengambilan data, peneliti menjelaskan maksud, tujuan penelitian, dan meminta persetujuan responden. Lansia diminta mengisi kuesioner karakteristik, setelah itu peneliti mengambil data nilai fungsi kognitif lansia dengan kuesioner MMSE. Dari penapisan menggunakan kuesioner MMSE, didapatkan sebanyak 2 lansia mengalami gangguan fungsi kognitif berat dengan nilai $\leq 18$ sehingga tidak dijadikan responden. Lansia dengan nilai MMSE > 18 diminta mengisi Global Physical Activity Questionnaire (GPAQ) yang berisi jadwal aktivitas sehari-hari lansia. Setelah dilakukan penapisan, 46 lansia dikeluarkan dari penelitian sehingga total sampel yang digunakan dalam penelitian ini sebanyak 84 lansia.

Karakteristik sosiodemografi responden didata menggunakan kuesioner karakteristik responden yang terdiri dari inisial, umur, agama, jenis kelamin, riwayat pendidikan, riwayat pernikahan, riwayat pekerjaan, dan penyakit penyerta. Variabel sedentary lifestyle diukur menggunakan GPAQ pada bagian "sedentary" yang telah diuji validitas dan reliabilitasnya di Indonesia oleh Bull et al. (2009). Uji reliabilitas instrumen tersebut menunjukkan nilai kappa $=0,78$ dan uji validitas instrumen tersebut menunjukkan nilai Spearman rho 0,83. ${ }^{14}$ GPAQ diterjemahkan oleh peneliti dengan back translation. Untuk menjawab pertanyaan dalam GPAQ pada bagian "sedentary", dibuat daftar aktivitas sehari-hari lansia disertai jam pelaksanaan tiap aktivitas. Dalam daftar aktivitas tersebut terdapat lima jenis perilaku sedentary lansia yaitu duduk membaca Alquran, duduk atau berbaring di kamar, duduk di acara pengajian, mengobrol sambil duduk dengan teman, dan duduk sambil 
menonton televisi. Dari pengisian kuesioner tersebut didapatkan total lama waktu sedentary lansia dalam satuan menit/hari.

Fungsi kognitif menggunakan kuesioner MMSE yang dimodifikasi dari Yellowless (2002). Kuesioner MMSE terdiri dari 11 item yang terbagi dalam 5 dimensi, yaitu dimensi orientasi, registrasi, atensi dan kalkulasi, mengingat kembali, dan bahasa. Nilai MMSE berkisar antara 0 - 30, semakin tinggi nilai MMSE maka fungsi kognitif semakin baik, sebaliknya semakin kecil nilai MMSE maka fungsi kognitif semakin buruk. Instrumen MMSE telah diterjemahkan serta diuji validitas dan reliabilitasnya di Indonesia oleh Palestin (2006). Uji validitas instrumen tersebut menunjukkan sensitivitas $100,0 \%$ dan spesifisitas 90,0\% sedangkan uji reliabilitas instrumen tersebut menunjukkan nilai Kappa $1,00(p=0,000) .{ }^{15}$

\subsection{Analisis data}

Analisis data dilakukan dengan perangkat lunak SPSS versi 20. Uji normalitas data dilakukan dengan uji Kolmogorov-Smirnov. Uji univariat estimasi lama waktu sedentary lifestyle dan fungsi kognitif lansia dilakukan menggunakan uji one sample KolmogrovSmirnov.

Analisis bivariat dalam penelitian ini dilakukan dengan uji Spearman Rank untuk mengetahui hubungan sedentary lifestyle dengan fungsi kognitif lansia di UPT PSTW Jember. Interval kepercayaan yang dipakai yaitu $95 \%$ sehingga apabila nilai $p<0,05$ dinyatakan bermakna secara statstik. Penelitian ini telah mendapat izin etik dari komisi etik Fakultas Kedokteran Gigi Universitas Jember dengan nomor 297/UN25.8/KEPK/DL/2019.

\section{Hasil}

Karakteristik responden dapat dilihat pada Tabel 1. Sebagian besar responden berjenis kelamin perempuan, beragama Islam, berpendidikan sekolah dasar (SD), bekerja sebagai buruh, dan tidak memiliki penyakit penyerta. Median usia responden adalah 70 tahun.
Penelitian ini mengukur lima jenis perilaku sedentary yaitu duduk membaca Alquran, duduk atau berbaring, duduk di acara pengajian, mengobrol sambil duduk dengan teman, dan duduk sambil menonton televisi. Jenis perilaku tersebut tidak semuanya dilakukan oleh responden sehingga data disajikan dengan mencantumkan jumlah responden pada setiap perilaku sedentary yang diukur. Lama waktu sedentary lifestyle lansia di UPT PSTW memiliki median 405 menit/hari (Tabel 2). Lama waktu sedentary lifestyle responden lebih

Tabel 1. Distribusi karakteristik responden $(n=84)$

\begin{tabular}{lr}
\hline Karakteristik Responden & $\mathbf{n ~ ( \% )}$ \\
\hline Usia, Md $\left(\mathrm{P}_{25}-\mathrm{P}_{75}\right)$ & $70(66,0-75,8)$ \\
Agama, $\mathrm{n}(\%)$ & \\
Islam & \\
Kristen & $1(1,2)$ \\
Jenis kelamin, $\mathrm{n}(\%)$ & \\
$\quad$ Laki-laki & $36(42,9)$ \\
Perempuan & $48(57,1)$ \\
Status pernikahan, $\mathrm{n}(\%)$ & \\
Menikah & $6(7,1)$ \\
Janda atau duda & $78(92,9)$ \\
Riwayat pendidikan, $\mathrm{n}(\%)$ & \\
Perguruan tinggi & $0(0,0)$ \\
SMA/SMK & $5(6,0)$ \\
SMP & $8(9,5)$ \\
SD & $42(50,0)$ \\
Tidak sekolah & $29(34,5)$ \\
Riwayat pekerjaan, $\mathrm{n}(\%)$ & \\
Pensiunan PNS/Polri/TNI & $1(1,2)$ \\
Pegawai swasta & $3(3,6)$ \\
Tidak bekerja & $13(15,5)$ \\
Wiraswasta & $33(39,3)$ \\
Buruh & $34(40,5)$ \\
Penyakit penyerta, $\mathrm{n}(\%)$ & \\
Tidak ada & $50(59,5)$ \\
Hipertensi & $34(40,5)$ \\
\hline
\end{tabular}

$\mathrm{n}(\%)$ : jumlah responden (persentase); $\mathrm{P}_{25}-\mathrm{P}_{75}$ : Persentil 25-75; SMA: sekolah menengah atas; SMP: sekolah menengah pertama; SD: sekolah dasar; PNS: pegawai negeri sipil; Polri: Kepolisian Republik Indonesia; TNI: Tentara Nasional Indonesia. 
Tabel 2. Distribusi sedentary lifestyle responden

\begin{tabular}{lcrcc}
\hline \multicolumn{1}{c}{$\begin{array}{c}\text { Sedentary Lifestyle } \\
\text { (menit/hari) }\end{array}$} & $\mathbf{n}$ & Median $\left(\mathbf{P}_{\mathbf{2 5}}-\mathbf{P}_{75}\right)$ & $\boldsymbol{Z}$ & $\boldsymbol{p}$ \\
\hline Duduk membaca Alquran & 23 & $30,0(30,0-30,0)$ & 2,437 & $<0,001^{\mathrm{a}}$ \\
Duduk/berbaring di kamar & 84 & $187,5(105,0-255,0)$ & 1,416 & $0,036^{\mathrm{a}}$ \\
Duduk di acara pengajian & 22 & $105,0(105,0-105,0)$ & 2,528 & $<0,001^{\mathrm{a}}$ \\
Mengobrol sambil duduk dengan teman & 82 & $210,0(90,0-210,0)$ & 2,663 & $<0,001^{\mathrm{a}}$ \\
Duduk sambil menonton TV & 26 & $120,0(120,0-120,0)$ & 2,663 & $<0,001^{\mathrm{a}}$ \\
Sedentary lifestyle total & 84 & $405,0(375,0-502,5)$ & 1,377 & $0,045^{\mathrm{a}}$ \\
\hline
\end{tabular}

$\mathrm{P}_{25}{ }^{-} \mathrm{P}_{75}$ : persentil 25-75; $\mathrm{n}$ : jumlah sampel; Z: nilai hitung uji Kolmogorov-Smirnov; ${ }^{2}$ nilai $\mathrm{p}$ pada uji KolmogorovSmirnov, dianggap bermakna bila $p<0,05$

Tabel 3. Fungsi kognitif responden $(n=84)$

\begin{tabular}{lrcc}
\hline Fungsi Kognitif & Median $\left(\mathbf{P}_{25}-\mathbf{P}_{75}\right)$ & $\boldsymbol{Z}$ & \multicolumn{1}{c}{$\boldsymbol{p}$} \\
\hline Orientasi & $10,0(8,0-10,0)$ & 2,522 & $<0,001^{\mathrm{a}}$ \\
Registrasi memori & $3,0(3,0-3,0)$ & 4,872 & $<0,001^{\mathrm{a}}$ \\
Atensi dan kalkulasi & $5,0(5,0-5,0)$ & 4,201 & $<0,001^{\mathrm{a}}$ \\
Pengenalan kembali (recall) & $3,0(3,0-3,0)$ & 4,952 & $<0,001^{\mathrm{a}}$ \\
Bahasa & $7,0(7,0-8,0)$ & 3,573 & $<0,001^{\mathrm{a}}$ \\
\hline Total & $27,0(24,0-29,0)$ & 1,401 & $0,040^{\mathrm{a}}$ \\
\hline
\end{tabular}

$\mathrm{P}_{25}-\mathrm{P}_{75}$ : persentil 25-75; $Z$ : nilai hitung uji Kolmogorov-Smirnov; ${ }^{a}$ nilai p pada uji Kolmogorov-Smirnov, dianggap bermakna bila $p<0,05$

rendah daripada nilai standar $(Z=1,377 ; p=0,045)$. Jenis perilaku sedentary yang tidak produktif yaitu mengobrol sambil duduk dengan teman, duduk atau berbaring di kamar, dan duduk sambil menonton televisi memiliki nilai median tinggi yaitu 210 menit/hari, 187,5 menit/hari, dan 105 menit/hari, sedangkan kegiatan produktif seperti membaca Alquran dan duduk di acara pengajian memiliki nilai median rendah, yaitu 30 menit/hari dan 105 menit/hari.

Hasil penilaian fungsi kognitif lansia di UPT PSTW Jember disajikan dalam Tabel 3. Tabel 3 menunjukkan median nilai fungsi kognitif lansia di UPT PSTW Jember sebesar 27 sehingga nilai fungsi kognitif responden lebih tinggi daripada nilai standar fungsi kognitif ( $z=1,401 ; p=0,040$ ). Berdasarkan hasil tersebut, diketahui bahwa lansia yang tinggal di UPT PSTW Jember tidak mengalami gangguan fungsi kognitif. Indikator yang memiliki median tertinggi yaitu orientasi dengan nilai 10 dan indikator yang memiliki median terendah adalah registrasi memori dan pengenalan kembali (recall) dengan nilai median 3 .

Hasil analisis menggunakan uji korelasi Spearman Rank (Tabel 4) menunjukkan $\mathrm{H}_{\mathrm{a}}$ diterima sehingga ada hubungan yang bermakna antara sedentary lifestyle dengan fungsi kognitif lansia. Semakin pendek waktu sedentary lifestyle maka fungsi kognitif lansia semakin tinggi $(r=-0,470 ; p$ $<0,001)$.

\section{Pembahasan}

Pada penelitian ini teridentifikasi adanya hubungan antara sedentary lifestyle dengan fungsi kognitif lansia di UPT PSTW Jember. Lansia yang lebih aktif beraktivitas fisik dan menggunakan waktu sedentary yang lebih pendek memiliki fungsi kognitif yang lebih baik. ${ }^{16}$ Oleh karena itu, diperlukan perhatikan khusus mengenai penggunaan waktu dan aktivitas yang dilakukan lansia. 
Tabel 4. Hubungan sedentary lifestyle dengan fungsi kognitif responden $(n=84)$

\begin{tabular}{cccc}
\hline \multirow{2}{*}{ Variabel } & Median $\left(\mathbf{P}_{25}-\mathbf{P}_{75}\right)$ & \multicolumn{2}{c}{ Fungsi Kognitif } \\
\cline { 3 - 4 } & & $\mathbf{r}$ & $\boldsymbol{p}$ \\
\hline Sedentary lifestyle (menit/hari) & $405(375-502,5)$ & $-0,470$ & $<0,001$ \\
\hline $\mathrm{P}_{25}-\mathrm{P}_{75}$ : persentil 25-75. & & &
\end{tabular}

Penelitian ini menunjukkan estimasi waktu sedentary lifestyle lansia lebih pendek pada nilai standar. Lama waktu sedentary lifestyle standar orang dewasa adalah selama 8 - 12 jam/hari. ${ }^{17}$ Lansia di Eropa menghabiskan waktu sedentary selama 5,3 jam. ${ }^{11}$ Sedentary lifestyle lansia di komunitas dikaitkan dengan hobi dan aktivitas fisik yang dilakukan lansia. Lansia yang hobi berolahraga dan gemar melakukan pekerjaan rumah ringan secara rutin memiliki waktu sedentary yang lebih pendek. ${ }^{18}$ Untuk itu, lansia tetap perlu melakukan aktivitas fisik ${ }^{19,20}$ yang biasa dilakukan setiap hari agar penggunaan waktu lansia lebih bermanfaat sehingga memperpendek waktu sedentary lifestyle.

Lansia dalam penelitian ini melakukan sedentary lifestyle untuk kegiatan yang tidak produktif, seperti duduk sambil mengobrol dengan teman, duduk atau berbaring di kamar, dan menonton televisi. Hal tersebut sesuai dengan pendapat Harvey et al. ${ }^{21}$ yang menunjukkan bahwa mayoritas lansia yang tinggal di komunitas menggunakan waktunya untuk sekadar duduk mengobrol dan menonton televisi. Sedentary lifestyle lebih sering dilakukan lansia karena kurangnya pengetahuan dan minat lansia yang berada di panti sosial untuk beraktivitas fisik. Pada lansia yang tinggal di komunitas, sedentary lifestyle dikaitkan dengan tingkat aktivitas fisik yang rendah. Untuk mengatasinya, diperlukan perencanaan latihan yang terstruktur dan diulang-ulang selama 150 menit dalam 1 minggu. ${ }^{22,23}$ Dengan hal tersebut, lansia diharapkan dapat meningkatkan aktivitas fisiknya secara teratur dan terjadwal guna mengurangi waktu sedentary lifestyle.

Lansia pada penelitian ini diestimasi memiliki fungsi kognitif utuh dan sebagian besar lansia memiliki riwayat pendidikan rendah. Berbeda dengan penelitian lain yang menyatakan bahwa lansia mayoritas mengalami gangguan fungsi kognitif terutama lansia dengan tingkat pendidikan rendah. ${ }^{24} \mathrm{Hal}$ tersebut terjadi karena kurangnya pengalaman mental dan lingkungan sehingga stimulasi intelektual kurang. ${ }^{24}$ Perbedaan hasil tersebut kemungkinan karena lansia di UPT PSTW Jember rutin mengikuti program mingguan antara lain senam, pengajian, dan pengembangan kreativitas yang dapat menstimulasi intelektual lansia. Penelitian yang dilakukan pada lansia di Denpasar didapatkan bahwa lansia yang rutin mengikuti senam berpeluang lebih besar memiliki fungsi kognitif utuh. ${ }^{25}$ Untuk itu, partisipasi lansia dalam senam diperlukan sebagai upaya untuk mempertahankan fungsi kognitif lansia tetap utuh sehingga kualitas hidup lansia bisa tetap dipertahankan. ${ }^{26}$

Pada penelitian ini teridentifikasi adanya hubungan antara sedentary lifestyle dengan nilai fungsi kognitif lansia di UPT PSTW Jember. Hal ini disebabkan karena sedentary lifestyle menghambat produksi BDNF di hipokampus yang berperan untuk mempertahankan fungsi kognitif seseorang, dimana protein tersebut hanya diproduksi apabila seseorang melakukan aktivitas fisik. ${ }^{12}$ Salah satu aktivitas fisik yang dilakukan di UPT PSTW secara rutin yaitu senam. Senam termasuk dalam latihan aerobik yang mampu mempertahankan fungsi kognitif lansia khususnya pada bagian kontrol eksekutif dan menjaga hipokampus yang berfungsi sebagai tempat menyimpan memori. ${ }^{27}$ Penelitian yang dilakukan pada lansia yang tinggal di komunitas menunjukkan bahwa lansia yang melakukan latihan aerobik termasuk senam mengalami peningkatan daya ingat (memori). ${ }^{28}$ Secara umum, World Health Organization merekomendasikan lansia melakukan latihan fisik aerobik selama 150 menit dalam 1 minggu. ${ }^{23}$ Latihan aerobik yang dilakukan secara 
rutin memperpendek waktu sedentary lifestyle baik pada lansia di panti sosial maupun di komunitas sehingga dapat mempertahankan fungsi kognitif tetap utuh.

Penelitian ini menunjukkan adanya hubungan antara sedentary lifestyle dengan nilai fungsi kognitif lansia. Meskipun demikian, metode potong lintang, yang digunakan hanya mengukur variabel dalam satu waktu. Penelitian ini juga hanya dilakukan di satu tempat sehingga tidak menutup kemungkinan apabila dilakukan di tempat lain didapatkan perbedaan hasil. Karakteristik dan jumlah sampel yang berbeda juga dapat memunculkan hasil yang berbeda, atau faktor penyebab, dan outcome bertukar posisi. Penelitian lanjutan diperlukan untuk menggali hubungan sedentary lifestyle dan durasi aktivitas fisik dengan fungsi kognitif lansia pada populasi umum.

\section{Kesimpulan}

Sedentary lifestyle berhubungan dengan fungsi kognitif lansia di UPT PSTW Jember. Perawat di UPT PSTW Jember hendaknya membantu lansia menyusun jadwal aktivitas fisik dan latihan yang lebih terstruktur sehingga waktu sedentary lifestyle lansia lebih pendek dan lansia dapat mempertahankan fungsi kognitif tetap utuh.

\section{Ucapan terima kasih}

Peneliti mengucapkan terima kasih kepada UPT PSTW Jember atas kerja sama dalam penelitian. Peneliti juga mengucapkan terima kasih kepada Kelompok Riset (KeRis) Healty and Wellness for Elderly dari Departemen Keperawatan Komunitas, Keluarga, dan Gerontik, Fakultas Keperawatan, Universitas Jember. Penelitian ini tidak menerima hibah dari lembaga pendanaan di sektor publik, komersial, maupun nirlaba.

\section{Konflik kepentingan}

Tidak ada konflik kepentingan dalam penelitian ini.

\section{Daftar pustaka}

1. Prince M, Comas-Herrera A, Knapp M, Guerchet $M$, Karagiannidou M. World alzheimer report 2016: Improving healthcare for people living with dementia. Coverage, Quality and costs now and in the future. London: Alzheimer's Disease International; 2016. 140 p.

2. Hurstak E, Johnson JK, Tieu L, Guzman D, Ponath $\mathrm{C}$, Lee $\mathrm{CT}$, et al. Factors associated with cognitive impairment in a cohort of older homeless adults: Results from the HOPE HOME study. Drug Alcohol Depend. 2017;178:562-70.

3. Kitamura K, Watanabe $Y$, Nakamura K, Sanpei K, Wakasugi M, Yokoseki A, et al. Modifiable factors associated with cognitive impairment in 1,143 Japanese outpatients: The Project in Sado for Total Health (PROST). Dement Geriatr Cogn Dis Extra. 2016;6(2):341-9.

4. Khairiah K, Mooi CS, Hamid TA. Prevalence and factors associated with mild cognitive impairment on screening in older Malaysians. Dusunen Adam. 2016;29:298-306.

5. Lee YJ, Kang HM, Kim NK, Yang JY, Noh JH, Ko $\mathrm{KS}$, et al. Factors associated for mild cognitive impairment in older Korean adults with type 2 diabetes mellitus. Diabetes Metab J. 2014;38(2):150-7.

6. Tremblay MS, Aubert S, Barnes JD, Saunders $\mathrm{TJ}$, Carson V, Latimer-Cheung $\mathrm{AE}$, et al. Sedentary Behavior Research Network (SBRN) - Terminology Consensus Project process and outcome. Int J Behav Nutr Phys Act. 2017;14:117.

7. Kirk-Sanchez NJ, McGough EL. Physical exercise and cognitive performance in the elderly: Current perspectives. Clin Interv Aging. 2014;9:51-62.

8. World Health Organization. Dementia: A public health priority. World Health Organization; 2015.

9. Program Profesi Ners. Laporan akhir program profesi ners (P2N) stase keperawatan gerontik di UPT PSTW Jember periode 18-30 September 2017. Jember: Program Profesi Ners; 2017. 
10. Mongisidi R, Tumewah R, Kembuan MAHN. Profil penurunan fungsi kognitif pada lansia di yayasan-yayasan manula di Kecamatan Kawangkoan. E-clinic J Ilm Kedokt Klin. 2013;1(1):3-6.

11. Harvey JA, Chastin SF, Skelton DA. How sedentary are older people? A systematic review of the amount of sedentary behavior. $J$ Aging Phys Act. 2015;23(3):471-87.

12. Xu, B. BDNF(I)rising from exercise. Cell Metab. 2013;18(5):612-4.

13. Manini TM, Carr LJ, King AC, Marshall S, Robinson TN, Rejeski WJ. Interventions to reduce sedentary behavior. Med Sci Sports Exerc. 2016;47(6):1306-10.

14. Bull FC, Maslin TS, Armstrong T. Global Physical Activity Questionnaire (GPAQ): Nine country reliability and validity study. J Phys Act Heal. 2009;6(6):790-804.

15. Palestin B, Nurachmah E, Ariawan I. Pengaruh umur, depresi dan demensia terhadap disabilitas fungsional lansia di PSTW Abiyoso dan PSTW Budi Dharma Provinsi D.I. Yogyakarta (adaptasi model sistem Neuman) [master's thesis]. Yogyakarta: Politeknik Kesehatan Kemenkes Yogyakarta; 2006.

16. Cohen $\mathrm{A}$, Ardern $\mathrm{Cl}$, Baker J. Inter-relationships between physical activity, body mass index, sedentary time, and cognitive functioning in younger and older adults: Cross-sectional analysis of the Canadian Community Health Survey. Public Health. 2017;151:98-105.

17. Australian National Preventative Health Agency. Obesity: Sedentary behaviours and health. Australia: Australian Government; 2014.

18. Muzamil MS, Afriwardi A, Martini RD. Artikel penelitian hubungan antara tingkat aktivitas fisik dengan fungsi kognitif pada usila di Kelurahan Jati Kecamatan Padang Timur. J Kesehat Andalas. 2014;3(2):202-5.

19. Anwari $M$, Vidyawati $R$, Salamah $R$, Refani $M$, Winingsih $N$, Yoga $D$, et al. Pemberian senam antihipertensi sebagai upaya menstabilkan tekanan darah: Studi kasus pada keluarga binaan di Desa Kemuningsari Lor Kecamatan Panti Kabupaten Jember. Indones J Heal Sci. 2018;Edisi Khusus:165-8.

20. Anwari M, Vidyawati R, Salamah R, Refani M, Winingsih $N$, Yoga $D$, et al. Pengaruh senam anti hipertensi lansia terhadap penurunan tekanan darah lansia di Desa Kemuningsari Lor Kecamatan Panti Kabupaten Jember. Indones J Heal Sci. 2018;Edisi Khusus:160-4.

21. Harvey JA, Chastin SF, Skelton DA. How sedentary are older people? A systematic review of the amount of sedentary behavior. $J$ Aging Phys Act. 2015;23(3):471-87.

22. Sauliyusta M, Rekawati E. Aktivitas fisik mempengaruhi fungsi kognitif lansia. J Keperawatan Indones. 2016;19(2):71-7.

23. World Health Organization. Global recommendations on physical activity for health. World Health Organization; 2010.

24. Rasyid IA, Syafrita Y, Sastri S. Hubungan faktor risiko dengan fungsi kognitif pada lansia Kecamatan Padang Panjang Timur Kota Padang Panjang. J Kesehat Andalas. 2017;6(1):49-54.

25. Lanawati, Listyowati R, Kuswardhani RAT. Hubungan antara senam kesegaran jasmani dengan fungsi kognitif dan keseimbangan tubuh lansia di Denpasar. Public Health and Preventive Medicine Archive 2015;3(2):211-7.

26. Susanto T, Widayati N. Quality of life of elderly tobacco farmers in the perspective of agricultural nursing: A qualitative study. Work. with Older People. 2018;22(3):166-77.

27. Bherer L, Erickson KI, Liu-Ambrose T. A Review of the effects of physical activity and exercise on cognitive and brain functions in older adults. J Aging Res. 2013;2013:1-8.

28. Bullock AM, Mizzi AL, Kovacevic A, Heisz JJ. The association of aging and aerobic fitness with memory. Front Aging Neurosci. 2018;10(63):17. 